\title{
Basel III in Reality
}

Michele Fratianni

Indiana University, Bloomington, USA

John C. Pattison

Financial Consultant, Toronto, Canada

\begin{abstract}
Financial regulation has shifted from a system as an oligopoly dominated by the G2/G5 to expanded clubs like the Basel Committee for Banking Supervision. Expansive clubs have to agree to terms that are closer to the preferences of soft-regulation members. Yet, once a global agreement on minimum standards, such as Basel III, is reached, the task is left to national or regional regulators. Deviations from the Basel III standards are bound to occur; the complexity of the agreement will facilitate an asymmetric implementation of national regulation and supervision. Countries like Australia, Canada, the United Kingdom, the United States, and some Scandinavian countries have chosen higher standards. On the other hand, we should expect deviations to take place in member countries of the Eurozone that are heterogeneous having different preferences and trade-off between regulatory stringency and economic activity. The requirements of both global clubs and regional club regarding transparency, monitoring, and a level playing field will also cause a collision. This paper reports examples of heterogenous applications of supervisions and reforms.
\end{abstract}

JEL Classification: F33, F36, F42

Keywords: Basel III, Clubs, Financial Regulation, Eurozone, Asymmetries

\footnotetext{
* Corresponding author: Michele Fratianni; Kelley School of Business, Indiana University, $10^{\text {th }}$ and Fee Lane, Bloomington, Indiana 47405, USA; Tel: +1 8128559219, Fax: +1 8128559210, E-mail: fratiann@indiana.edu.

Co-Author: John C. Pattison; Financial Consultant, 61 St. Leonard's Avenue, M4N1K1, Toronto, Canada; Tel: +1 4164815139, Fax: +1 4164815139, E-mail: johnpattison@rogers.com.
} 


\section{Introduction}

The oversight of financial markets has been under scrutiny since the 2008 financial crisis. The sovereign debt crisis in the Eurozone (EZ) periphery has caused political tensions arising from different preferences among member countries for tighter regulation versus short-term economic growth. These tensions created pressure for a weaker and delayed implementation of regulation agreed within the setting of two financial clubs with an expansive membership, the Basel Committee on Banking Supervision (BCBS) and the Financial Stability Board (FSB). ${ }^{1}$

These committees, both global and regional, are in essence, the extended financial clubs that shape the approaches, methodology, quantification, and calibration of regulation across countries. They create a public good in the form of international financial standards (Kindleberger 1983). ${ }^{2}$ Standards generate economies external to the firm and reduce transaction costs by lowering risk and uncertainty. They may be implemented by producers rather than imposed by governments. ${ }^{3}$ In Europe, the interests of global versus regional clubs intersect and conflict: conflicts being both internal within each club and between clubs. Financial regulators are members of dozens of such clubs, such as the European Union (EU), the Bank for International Settlements (BIS), the OECD, and the FSB. Traditionally, the multiplicity of clubs leads to forum shopping. However, in the case of financial regulation, the BCBS, the FSB and the EU set binding minimum requirements and there are processes for oversight, assessment and disclosure of failures to comply that affect macroeconomic policy and politically sensitive institutions.

Today, the best argument for financial regulation rests on network effects. Individuals and institutions suffer from asymmetric information and cannot properly assess the credit risk of their counterparties in a financial transaction. In times of financial turmoil, mistrust in counterparties becomes paramount, as demonstrated in the aftermath of the failure of Lehman Brothers in October of 2008.

The performance of financial clubs is sensitive to specific shocks or problems that affect the types of regulation and their timing in individual countries. Performance is

\footnotetext{
${ }^{1}$ See Appendix 1 for a list of clubs, membership, and their functions.

${ }^{2}$ Kindleberger's characterization is that "they are a strong form of public good in that they have economies of scale" (1983, p. 377).

${ }^{3}$ On this, Kindleberger points out that "Governmental standards may turn out to be dubious public goods and at the same time collective bads" (1983, p. 381).
} 
also sensitive to the composition of an expanded membership that accentuates club heterogeneity: the economic incentives of new, small, and financially underdeveloped members do not match those of the old, large, and financially well-developed members. Conflicts arising from membership heterogeneity imply that European financial clubs face a difficult task in achieving common regulatory standards. Because of these conflicts, four issues stand out. (i) The single market demands a common regulatory framework to avoid distorting competition. In a heterogeneous club, the implementation of a single standard is not an equilibrium outcome. National preferences for regulation are shaped by the relative importance of the banking sector, tradeoffs between regulatory stringency and other macro-economic objectives, the intensity of industry lobbying for weaker regulation and governments' capacity to resist such lobbying. The interests of Wall Street, which thrives when risk-taking is encouraged, may not coincide with those of Main Street, which performs better with a more stable flow of bank credit (Korinek and Kreamer 2014). In this scenario, the regulator trades off efficiency in the financial sector against efficiency in the real sector. (ii) In an incomplete and fragile monetary union like the EZ, fiscally disciplined members are exposed to the financial risks emanating from fiscally undisciplined members that carry a higher credit risk and yet share common currency. (iii) In a financial crisis, political pressure is exerted to soften regulation to help weaker members to protect undercapitalized institutions and to stimulate their economies; the larger the pressure is, the greater the asymmetries in the impact of the crisis across member states. (iv) The intersection of regional and global regulatory clubs: the heterogeneity of a regional club compounds the already difficult bargaining process with other countries, regional clubs, and international organizations to achieve common financial standards on a global basis.

The remainder of this paper proceeds as follows. Section II provides an analysis of the shift from oligopoly-type clubs to expansive clubs in generating international cooperation on financial regulation. Section III then outlines the main elements of the complex Basel III agreement and the differences in its implementation in two large economic areas, the EU and the US. Section IV discusses the conflict between the single rulebook, the common standard underlying a single market for banking desired by EU policy makers, and the incentive of member countries to implement the rulebook flexibly. Flexible implementation, in turn, is driven by an incomplete and fragile EZ construction and significant member country heterogeneity. Conclusions are drawn in Section V. 


\section{Oligopoly Policy Formation vs. Regulation by Committee}

After the Second World War, the largest countries initiated cooperative actions, governed important international organizations, structured and negotiated policy changes, and were critical in implementing the policies of these organizations. In the regulatory field, it is hard to think of international standards that did not start out as the public good of some particular country, usually one with high international standing because of its economic and/or military power (Kindleberger 1983, p. 392). Originally, the G-5, G-7, and G-10 were the key small-number clubs. The capital rules of the Basel I Accord of 1988 were worked out between the United States (US) and the United Kingdom (UK) and then sold to other countries through the auspices of Basel Committee on Banking Supervision (BCBS). The Basel II and Basel III Accords, developed during the first decade of the $21^{\text {st }}$ century, are instead products of expansive committees. In less than twenty years, we have moved from a decision-making process dominated by few critical players, organized in small and homogeneous clubs, to a process where agreements and decisions are taken within the setting of large-number clubs. In the case of the important BCBS, membership expansion has taken place by including a growing number of countries with relatively small financial sectors; see Appendix 1.

Cooperation in financial regulation occurs if countries expect to receive net benefits from it. Under this condition, they are willing to invest political and financial capital. An oligopoly of nations creates incentives for large countries to lead in this cooperative effort. Large countries, by virtue of their size, gain the most from cooperation and consequently are willing to bear proportionately higher costs to achieve it. Since costs occur before benefits, a large country will invest in cooperation if it is reasonably certain to obtain sufficiently large benefits to justify the investment. Small countries, on the other hand, generate small policy contributions to a club and tend to free ride on the policies and investments made by large countries; free-riding is facilitated by their small policy contributions. As Olson aptly put it (1973, p. 24): "What matters most is not how much of the collective good will be provided if some is provided, but rather whether any of the collective good will be provided." In other words, the conditions for the creation of cooperative action are restrictive and thus free-riding behavior needs to be managed. Olson's insight is that the conditions for cooperation are limiting. However, in the European case the regulatory club had been created prior to the divisive tensions arising from the financial and sovereign debt crises. One implication is that new agreements 
would not deliver benefits to all EU countries, as many of these countries have vastly different needs and preferences. The negotiating challenge is to agree to international standards such as the BCBs or FSB, while permitting some latitude to reach national or regional aims. This may be achieved by putting pressure on global clubs to lower standard, by delays in implementation, opaqueness, or leaving sufficient discretion to avoid full compliance.

In searching for the optimum amount of cooperation, there is a difference between what an individual country wants and what a group of countries may wish (Fratianni and Pattison 1982). Each member makes a decision to maximize net benefits from membership, likely in the form of marginal policy contributions which translate into economic and financial gains. In a symmetric world, populated by a large number of small countries, the contribution of an individual country to a cooperative activity, in terms of both information content and policy contribution, would be small. A club could not be created or sustained because incentives for cooperation would be diffused across many issues unrelated to one another. The model would predict decreasing cooperation as financial markets become more dispersed. In an asymmetric world, populated by a few large countries and many small countries, the contribution to a cooperative activity of some countries becomes economically significant. These incremental benefits decline as large countries add smaller countries to the club. But as countries are added, the likelihood of conflicts among members rises and so do the costs of sharing and interpreting more complex information, as well as decision-making processes; in essence, the marginal costs of running a club rise. Thus, the optimal number of members in a club is determined by the interaction of how fast marginal benefits from cooperation decline and marginal costs rise as new members are added.

Other issues include: the origination of cooperative activity; the payoff and reaction matrices and how the game is played by clubs; the incentives and behavior of big and small members; the operations and policy recommendations of international organizations and how these influence club members, in particular with regard to questions of funding, structure, governance, and voting. This paper's assessment is that the oligopoly model accounts for the establishment of the central organization and a great deal of cooperative origination in the context of Bretton Woods institutions. During the fixed exchange rate regime of the gold-dollar exchange standard, member countries valued knowledge about current and future economic developments in Germany, Japan, the US, and the UK. This informational process was enhanced by frequent intergovernmental meetings where member countries would receive private information 
on political attitudes and economic policy in the critical countries. The G-10 group of countries, created in 1961, played a strong role in the International Monetary Fund (IMF), the Organization for Economic Cooperation and Development (OECD), and the Bank for International Settlements (BIS). Participation in the important OECD Working Party 3, dealing with balance of payments, was restricted to the G-10, the European Union, and two observers, the IMF and the BIS. The central banks of the G-10 countries continue to meet, without much publicity but great effectiveness, once a month at the BIS (Fratianni and Pattison 2001). The G-5, a sub-group of the G-7 created in 1973, achieved significant exchange rate coordination in the mid-1980s and their activities paved the way for the IMF to engage in the so-called multilateral surveillance (Boughton 2001, chapter 4).

It has already been noted that global standards have moved from an oligopoly setting with Basel I to an expanded-club setting with Basel II and III. The inference is that economics and politics no longer encourage industrial countries with large and dominant global financial markets to initiate new rules. Several factors are at play. The first is legitimacy. Small clubs exude secrecy and exclusion. Those who are excluded clamor for a more democratic approach. Large countries may have felt the pressure of world opinion turning against them. This pressure has contributed to the widely held view that the regulatory frameworks of the US and the UK have been tarnished by the financial crisis. The consequent loss of reputational capital weakened the leadership of these two countries in initiating global rules and in sustaining the success of small-number financial clubs.

Political pressure alone, however, cannot explain membership expansion. Economic power has shifted from the core industrial countries, defined by membership in clubs like the G-5 or G-7, to emerging market economies, defined by country groupings like BRIC (Brazil, Russia, India, and China). During the Bretton Woods period, the G-5 group, consisting of France, Germany, Japan, the US, and the UK held an extremely high and constant share of approximately $85 \%$ of OECD GNP (Fratianni and Pattison 1982, Table $2)^{5}$ Today, the economic power of core industrial countries has declined significantly relative to emerging market economies; see Appendix 1.

The third reason for membership expansion stems from the fact that with the globalization of financial markets, more countries have become active in updating

\footnotetext{
${ }^{4}$ For details of the two exchange rate accords, the Plaza of 1985 and Le Louvre of 1987, see Funabashi (1988).

${ }^{5}$ This paper uses world GNP or GDP shares as a proxy of the club's policy contribution.
} 
national financial regulation. Also, more countries can create and transfer risks to core countries. In terms of the club model, this implies that the marginal benefits schedule from cooperation has shifted upward, justifying an expansion of the number of players in international rule making. The fourth reason is that the spread of financial institution subsidiaries from large countries to less regulated locations has raised the benefit to large countries of being more inclusive in setting global standards. Global institutions lower their costs when regulation is more homogeneous; also homogeneous regulation must satisfy lower standards to be agreed to by a larger number of countries, a factor not lost on financial institutions.

The final reason has to do with one of the assumptions of the traditional club model, namely that the inclusion of a small country in a club generates negligible marginal value of information and policy contribution, while considerably raising the marginal cost of decision making to the club as a whole and to individual members. The relative irrelevance of small countries in a club is based on the assumption that these countries do not create significant economic and political spillovers; it would behoove the club to include them and set rules that would minimize the occurrence of conditions which would lead to such spillovers.

Greece is an example of significant spillovers from a small to large member countries of a monetary club. In December 2009, Greece, which had suppressed information about the size of its budget deficit, received a sharp credit rating downgrade. This, in turn, triggered massive capital outflows and sudden-stop episodes, not only in Greece, but in other southern countries of the EZ (Merler and Pisani-Ferry 2012). Sovereign bond yields in these countries suffered a steep rise in a period of otherwise stable or moderately declining global risk aversion (Alessandrini et al. 2014). This is a classic case of a small country imposing negative information value on other club members. The reason for the spillovers has to do with an inadequate adjustment mechanism in the EZ (Dellas and Tavlas 2013). In the international gold standard, countries that adhered to it faced an effective balance-of-payments constraint: when the fundamentals of fiscal policy deteriorated sovereign credit risk and domestic interest rates rose, prompting policy makers to take corrective actions that would restore equilibrium in the balance of payments. This mechanism has not been present in the EZ. Greece, and also other member countries, were not penalized by the financial markets for their poor fundamentals for a long time because of a presumption that fiscally profligate countries would be bailed out. In sum, a faulty design mechanism was responsible for a deviating small member country imposing large negative spillovers onto larger member countries. 


\section{Basel III, Complexity, and the Single Rulebook}

Basel III has been in the making beginning with the move to Basel II which commenced in 1999. While refinements to this agreement remain to be finalized, its main structure is in place. Implementation at the national and regional level is well underway. The US has approved its own new set of regulations under the rubric of Final US Rules that incorporate Basel III norms as well as provisions of the Dodd-Frank Act. ${ }^{6}$ The EU has transposed Basel III in a Capital Requirement Regulation and a Capital Requirement Directive (CRD), jointly known as CRD IV, which entered into force on July 17, 2013 (European Commission 2013b). Twenty-five of the twenty-seven jurisdictions that are members of the BCBS have issued Basel III capital regulations (BCBS 2013).

Despite the immense effort that has gone into the Basel III agreement, significant differences across countries can be expected. Basel III sets minimum standard levels and countries are free to choose tougher standards. Banking centers that want to establish or maintain a high safety reputation may decide to go above the minimum levels agreed by an expansive club whose members are heterogeneous in their regulatory preferences. The EU is aware of this outcome and has been keen at eliminating the threat of member countries' differences in regulatory standards. At one time, the European Commission and some member countries sought to require a maximum amount of harmonization to prevent a race to the top, which would have benefitted member countries (Masters and Cohen 2011, p. 3). The proposal failed either because some members wanted to safeguard taxpayers against losses from unsafe financial practices or because it was not incentive compatible for finance-intensive members. In June of 2009, the Council of the European Union (2009) recommended establishing a single rulebook for all financial institutions in the single market. ${ }^{7}$ In 2013, the European Commission (2013a, p. 2) stated that a single rulebook is crucial to ensure that there are no loopholes and good regulation everywhere in order to guarantee a level playing field for banks and a real single market for financial services. In 2014, the Eurozone launched a comprehensive assessment of approximately 130 globally systemically important banks. The

\footnotetext{
${ }^{6}$ Board of Governors of the Federal Reserve System, Basel Regulatory Framework (http://www.federalreserve.gov/bankinforeg/basel/ USImplementation.htm\#baseIII).

On page 8, the document states: The European Council agrees that the European System of Financial Supervisors should have binding and proportionate decision-making powers in respect of whether supervisors are meeting their requirements under a single rule book and relevant Community law and in the case of disagreement between the home and host state supervisors, including within colleges of supervisors.
} 
assessment consisted of two phases, an asset quality review and a stress test, both of which were concluded on October 26th. In early November, the 130 banks became subject to a Single Supervisory Mechanism (ECB 2014). An interesting aspect of the entire exercise was the extent to which the value of bank equity differed between the assessment by national authorities and the assessment done by the ECB, both using the same bank information (end of 2013) and applying the same criteria codified by the single rulebook. Greek banks, on average, had the largest discrepancy: the Tier 1 common equity ratio was valued 2.9 percentage points higher by the national regulator than by the ECB; Italian banks had a positive discrepancy of 1.1 percentage points; French and German banks a discrepancy of 0.2 percentage points. These results are consistent with our point that national preferences for regulation differ. These differences, coupled with the complexity of Basel III, are likely to generate and sustain substantial regulatory heterogeneity across countries. 
Table 1. Basel III implementation in the European Union and the United States

\begin{tabular}{|c|c|c|c|}
\hline Regulation & United States & European Union & Comment \\
\hline $\begin{array}{l}\text { CET } 1, T 1, \& \\
\text { T2 ratios }\end{array}$ & $\begin{array}{l}\text { Ratios of } 4.5 \%, 6 \% \text {, and } \\
8 \% \text { conform to Basel III but } \\
\text { additional restrictions apply }\end{array}$ & $\begin{array}{l}\text { Ratios conform } \\
\text { to Basel III }\end{array}$ & $\begin{array}{l}\text { The US has tighter } \\
\text { restrictions because of the } \\
\text { Dodd-Frank Act }\end{array}$ \\
\hline $\begin{array}{c}\text { Capital conservation } \\
\text { buffer }\end{array}$ & $2.5 \%$ conform to Basel & $\begin{array}{c}2.5 \% \text { conform to Basel; } \\
\text { enforcement by national } \\
\text { supervisors }\end{array}$ & $\begin{array}{l}\text { Potential deviation from } \\
\text { single rulebook by EU } \\
\text { member countries }\end{array}$ \\
\hline $\begin{array}{l}\text { Countercyclical } \\
\text { capital buffer }\end{array}$ & $\begin{array}{l}2.5 \% \text { CET1 may apply only } \\
\text { to AAB banks }\end{array}$ & $\begin{array}{l}2.5 \% \text { CET1 applies } \\
\text { to all FIs; enforcement } \\
\text { by national supervisors }\end{array}$ & $\begin{array}{l}\text { Potential deviation from } \\
\text { single rulebook by EU } \\
\text { member countries }\end{array}$ \\
\hline Systemic risk buffer & Not yet decided & $\begin{array}{l}\text { National supervisors } \\
\text { have the power }\end{array}$ & $\begin{array}{c}\text { Potential deviation from } \\
\text { single rulebook by EU } \\
\text { member countries }\end{array}$ \\
\hline G-SIB surcharge & Not yet decided & $1 \%$ to $3.5 \% \mathrm{CET} 1$ & US more restrictive \\
\hline $\begin{array}{l}\text { Asset risk weighting } \\
\text { methodology }\end{array}$ & $\begin{array}{c}\text { Standardized approach } \\
\text { obligatory, IRB can be added }\end{array}$ & $\begin{array}{l}\text { Standardized and IRB } \\
\text { approaches may be } \\
\text { alternatives }\end{array}$ & US more restrictive \\
\hline External credit ratings & Not permitted & Permitted & US more restrictive \\
\hline Sovereign debt & $\begin{array}{c}0 \% \text { US, } 20 \% \text { US conditional, } \\
0 \% \text { to } 150 \% \text { non-US } \\
\text { sovereigns }\end{array}$ & $\begin{array}{c}0 \% \text { EU governments, } \\
0 \% \text { to } 150 \% \\
\text { non-US sovereigns }\end{array}$ & US more restrictive \\
\hline $\begin{array}{l}\text { Loans secured by } \\
\text { property }\end{array}$ & $\begin{array}{l}50 \% \text { high quality, } \\
100 \% \text { others }\end{array}$ & $35 \%$ & US more restrictive \\
\hline $\begin{array}{l}\text { Exposure in default } \\
\text { and arrears }\end{array}$ & $\begin{array}{l}\text { The US has higher } \\
\text { weighting than the EU }\end{array}$ & $\begin{array}{l}\text { The US has higher } \\
\text { weighting than the EU }\end{array}$ & US more restrictive \\
\hline Equity exposure & $\begin{array}{l}\text { The US has tighter } \\
\text { restrictions than the EU }\end{array}$ & $\begin{array}{l}\text { The US has tighter } \\
\text { restrictions than the EU }\end{array}$ & US more restrictive \\
\hline Off-balance sheet & $\begin{array}{l}\text { The US and EU } \\
\text { are similar }\end{array}$ & $\begin{array}{l}\text { The US and EU } \\
\text { are similar }\end{array}$ & US and EU similar \\
\hline $\begin{array}{l}\text { Securitized } \\
\text { transactions }\end{array}$ & $\begin{array}{l}\text { Not yet compliant } \\
\text { with Basel III }\end{array}$ & $\begin{array}{c}\text { Compliant with } \\
\text { Basel III }\end{array}$ & EU more restrictive \\
\hline Derivatives - OTC & $\begin{array}{l}\text { The US follows a different } \\
\text { approach than Basel III }\end{array}$ & $\begin{array}{c}\text { The EU follows } \\
\text { Basel III }\end{array}$ & Different approaches \\
\hline $\begin{array}{c}\text { Credit valuation } \\
\text { adjustment }\end{array}$ & The US follows Basel III & $\begin{array}{c}\text { The EU does not follow } \\
\text { Basel III }\end{array}$ & Different approaches \\
\hline $\begin{array}{l}\text { Liquidity } \\
\text { requirement }\end{array}$ & $\begin{array}{c}\text { The US goes beyond Basel III } \\
\text { because of Dodd-Frank Act }\end{array}$ & The EU follows Basel III & The US has tighter restrictions \\
\hline $\begin{array}{l}\text { Leverage } \\
\text { requirement }\end{array}$ & $\begin{array}{c}4 \% \text { for depository } \\
\text { institutions; } 3 \% \text { for AABs }\end{array}$ & $3 \%$ & $\begin{array}{l}\text { The US has tighter restrictions, } \\
\text { but new developments are } \\
\text { in the making }\end{array}$ \\
\hline $\begin{array}{c}\text { Community/small } \\
\text { banks }\end{array}$ & $\begin{array}{l}\text { US sets higher standards for } \\
\text { AABs and large banks than } \\
\text { community banks }\end{array}$ & $\begin{array}{l}\text { No difference in stan- } \\
\text { dards between large and } \\
\text { small banks }\end{array}$ & US more flexible \\
\hline
\end{tabular}

(Notes) Abbreviations are as follows; CET1=Common Equity Tier 1 capital; T1=Tier 1 capital; T2=Tier 2 capital; $\mathrm{AAB}=$ Advanced Approaches Bank; FI=Financial Intermediary; G-SIB=Globally Systemically Important Banks; IRB = Internal Ratings Based.

(Sources) Shearman and Sterling (2013); website of the Board of Governors of the Federal Reserve System. 
Table 1 summarizes how the main parts of Basel III have been implemented, as of the end of 2013, in two large economic areas of the world, the EU and the US. The table, naturally, cannot do full justice to the scope and depth of the agreement that runs well over 1,000 pages if one includes rules on market risk and leverage ratio. Four observations, however, are pertinent. The first is that Basel III is very complex in terms of data, analytics, implementation, and reporting. It contains some untested and difficult to quantify provisions. Complexity will raise not only the cost of bank compliance, but also the cost of enforcement to authorities. Some regulation, such as the countercyclical capital buffer, will require interpretation of macro-economic data on the part of regulators and thus poses its own risks of implementation. Complexity will also force bank examiners to make more judgment calls. Consequently, regulatory discretion will rise; this, in turn, will not be uniform across nations. There is general acceptance that cross-country variation in risk-weighted assets reflects not only differences in business models, risk profiles, and accounting rules but also different assessments of credit risk, and forbearance by national regulators and supervisors. ${ }^{8}$ Different supervisory assessments, in turn, cannot be divorced from different national preferences for regulation and tradeoffs between regulation and important macro-economic objectives. Since regulatory stringency has a larger impact on bank lending in a bank-centric system than in a market-centric system, it is to be expected that regulators and supervisors from bank-centric systems be sensitive to this correlation and consequently behave differently than their counterparts in market-centric systems. Furthermore, to the extent that national preferences about the trade-offs between regulatory stringency and bank lending differ, it is to be expected that supervisory assessments and enforcement will also reflect such differences. More analysis of this dynamic will be provided below.

The second observation is that there are significant differences between the EU and the US in implementing Basel III. The US is more restrictive than the EU on capital requirements, liquidity requirements, leverage requirements, external credit ratings, and loans secured by property. While the Dodd-Frank Act is the legislative tool responsible for most of these differences, the underlying impetus was the drive to regain reputation lost during the sub-prime mortgage crisis. On the other hand, the US has implemented a dual-regulatory system, one that is applicable to very large banks (Advanced Approaches Banks) and another to community or smaller banks. The latter face smaller riskweighted capital ratios than the former and are exempt from the countercyclical capital

\footnotetext{
${ }^{8}$ Leslé and Avramova (2012) report on such differences using a sample of 50 large banks in the Asia Pacific region, Europe, and North America.
} 
buffer requirement. In contrast, the EU does not make any distinction between very large banks and community banks. Other examples of more stringent regulation above international standards and faster implementation are Australia, Canada, Switzerland, some Scandinavian countries, and the United Kingdom. The third observation is that there are plenty of opportunities in the EU to deviate from the single rulebook. The position of the EU Commission, which is reflected in CRD IV, is to prohibit a race to the top in capital requirements because it would be against the interests of some member countries and would encourage regulatory arbitrage. ${ }^{9}$ Yet, Table 1 identifies at least three areas, the capital conservation buffer, the countercyclical capital buffer, and loans secured by property, where national regulators and supervisors can exercise discretion. This is in addition to the large number of specific discretions allowed in the Basel rules. The extent of this discretion will depend on national preferences for regulation and the nature of the tradeoff between regulation and other economic objectives. The last observation concerns exposures to sovereign debt. While there are some differences between the EU and the US, the common and sharp anomaly is to treat sovereign debt as riskless. Furthermore, concentration risk does not apply to government securities unlike corporate securities. The EU applies zero weighting, not only to EU member states, but also to all OECD countries, as was true in Basel I and II. The US relies on the Country Risk Classification Codes of the OECD to calculate risk weighting. Neither area legislates a home bias in the treatment of sovereign risk, but in fact banks have a distinct preference for domestic sovereigns over foreign sovereigns for strategic reasons, such as being considered too big to fail, the need for greater local currency liquid assets, foreign exchange risk, and potential preferential treatment by domestic governments in case of debt restructuring. To regulate the complete safety of debt sovereigns in light of what has happened in Europe is no longer justifiable. EBA (2013b) reports that 64 large banks, at the end of June of 2013, faced an exposure to sovereign debt of 1,585 billion euro, of which $68 \%$ issued by domestic governments. For Italian and Spanish banks, sovereign debt exposure represents approximately $10 \%$ of total bank assets. The International Financing Review (Gareth Gore 2014) reported that "the sovereign bond portfolios of eurozone banks reached a record 2.4 trillion euro in September, according to the ECB. That is $30 \%$ higher than in $2011 \ldots$ such positions can be taken without holding regulatory capital, unlike other loans...Banks with capital constraints thus can borrow cheaply

\footnotetext{
${ }^{9}$ Empirical evidence of regulatory arbitrage emerges from an examination of cross-border mergers and acquisitions (Carbo-Valverde et al. 2012, Karolyi and Taboada 2013). Abnormal rates of returns are observed around announcement dates for acquiring banks located in countries with higher regulation and supervision.
} 
from the ECB - and reap the profits of the trade without the need to muster additional capital."

On January 12, 2014, the Group of Governors and Heads of Supervision endorsed the new softer BCBS guidelines concerning leverage and net stable funding ratios. For the leverage ratio, the softening comes not from a lower value of the ratio, but through changes on what qualifies as assets. Limited netting, i.e., differences between assets and liabilities relative to a given counterparty, will be permitted on transactions such as repos and reverse repos, thus reducing the denominator of the leverage formula. Derivatives will be counted on a net basis, again lowering the denominator of the formula. As for the net stable funding ratio, the changes would allow the inclusion of funding with maturities slightly less than a year. It should be stressed that the UK, the US, and some other regulators desire tighter standards and are not favorable to a dilution of the leverage ratio, which is preferred to risk-weighted measures that can be easily gamed by banks (Jones 2014). ${ }^{10}$

\section{Eurozone Asymmetries and Regulation Heterogeneity}

In this section, three issues will be discussed involving the unique characteristics of the EZ given its treaties and agreements: (i) To what extent the oligopoly model applies to the EZ where the largest countries are tied to the smallest ones by a currency union and a high degree of financial integration; (ii) Does a currency union enhance the relative power of fiscally undisciplined countries? (iii) Will the single rulebook survive different national preferences for regulation and the tradeoffs with other important macroeconomic variables?

\footnotetext{
${ }^{10}$ Andrew Haldane, the director for financial stability at the Bank of England, has proposed a simplification of capital ratios (Jones 2014). Note that British and Swiss banks have tighter liquidity rules than those of Basel III. Switzerland is a member of the European Economic Space as an ex-EFTA member. Both countries raised their requirements prior to the publication of the international rules because both faced large domestic financial risks with banking assets many times that of GDP.
} 


\section{A. Eurozone asymmetries}

The Eurozone has never met the conditions for an optimal currency area. The drafters of the Maastricht Treaty were aware of this but were driven by political motivation and by the expectation that fiscal and political union would follow monetary union before long. History proved them wrong and the EZ architecture has remained incomplete and fragile. The North of Europe is very different from the South, not only in terms of fiscal profligacy, but also with respect to competitiveness that shows up in external imbalances (Alessandrini et al. 2014). Many of the characteristics typical of the Italian Mezzogiorno problem have resurfaced in the EZ, except that the mechanism to stabilize a monetary union that is also a fiscal union is absent in the EZ. The upshot is that the latter resembles more inter-governmental agreement than a supranational entity. Panetta $(2014$, p. 2) emphasizes that the monetary policy regime "cannot take into account the heterogeneity among member states and its transmission mechanism has been weakened by financial fragmentation."

As a magnified inter-governmental agreement, the EZ illustrates the fundamental difference between creating a club and managing it. France and Germany, two of the larger countries, were the impetus behind the creation of the monetary union. The payoff for the large countries was trade deepening and financial integration. The payoff for the small countries was lower interest rates from higher collective credit ratings and the elimination of currency risk to investors. As for credit risk, the club set rules to reduce the likelihood that profligate member countries would damage the monetary union: the two most important ones were restrictions on government deficits and the introduction of an anti-solidarity norm aimed at insulating the club from the spillovers of a member's default. ${ }^{11}$ But the rule on deficits was not seriously enforced and the anti-solidarity rule was not taken as fully credible by the market. The periphery rode freely on the lower interest rates achieved by the center and postponed needed adjustments and reforms. Neither the club nor its large members took actions to remedy this classic flaw of club behavior. The financial crisis, but especially the revelation of Greece's fiscal disarray at the end of 2009, unequivocally showed the deep cracks within the monetary union house.

To summarize the main lesson of club behavior, peripheral countries have exerted disproportionate power in relation to the size and relevance of their economies and

\footnotetext{
${ }^{11}$ Art.104 of the EU Treaty deals with fiscal rules and their enforcement; Art. 103 states the no bail out clause (also known as the nonsolidarity clause), but Art. 100 introduces conditions for solidarity.
} 
financial centers. This is typical free riding emphasized by Olson (1965), Mancur Olson and Richard Zeckhauser (1966), and Fratianni and Pattison (1982). Casella (1992) provides an alternative explanation for the disproportionate power of small players: "In a cooperative agreement, if power were proportional to size, small countries would have very little control over common decisions; they would be bound by the discipline of the accord without being able to address their own specific interests." It is correct to say that the EZ is a voluntary agreement and all participants must feel they have a say in this agreement. On the other hand, unlike other clubs, the EZ has no expulsion clause. A non-compliant member cannot be kicked out. The exit door is open only for those who voluntarily take it. By the time the damage is revealed, it may be too costly for the large, compliant countries to pull out and form another, more homogeneous monetary club. This is what happened with Greece in 2010: Greek bonds were held by EZ banks, especially those located in France and Germany, as well as by the ECB. A Greek default and a break in the monetary union would have undermined the capitalization of EU financial institutions, which had already been debilitated by the sub-prime mortgage crisis. The outcome was that the large countries put together a rescue package for Greece.

\section{B. Regulation heterogeneity}

Having noted the inherent asymmetries, the obvious question is whether the single rulebook of financial regulation will survive in the presence of transparency and monitoring including peer reviews. With monetary union, monetary policy is common to all member countries. Without a centralized government budget and a transfer mechanism that compensates for asymmetric national shocks, member countries must rely on national fiscal policy for countercyclical policy. However, since the Greek shock, the prevailing regime has been one of fiscal austerity. The single rulebook would impose another common standard across heterogeneous countries. Common financial regulations, in addition to a common monetary policy and constrained fiscal policy, would further reduce the few degrees of freedom left to national macroeconomic policy.

Country heterogeneity and different tradeoffs between prudential financial regulation and fostering national economic activity encourage deviations from the single rulebook. The evidence shows that gains from coordination of regulation occur when shocks are symmetric (Masson and Pattison 2009). If shocks are instead vastly different, a 
small country may have little or no incentive to cooperate. In the case of complete globalization, a high degree of competition amongst countries triggers incentives to harmonize regulation to prevent a race to the bottom. This is the principle underlying the EU implementation of directives for minimum regulation of many industries, notably banking. Basel III is another example, but, as shown above, its web of regulation is so complex that it would be easy for institutions or national regulators to cheat. The nexus between complexity and difficulty of monitoring uniformity may reflect the role of national asymmetries and why so many countries have shown a willingness to follow Basel III.

Here are some examples of heterogeneous application of regulation and supervision:

- The EBA carries out periodic investigations into the implementation of regulation such as the consistency of risk-weighted assets. It reports significant variation in risk weights arising from estimated parameters, such as the probability of default and the loss given default. It has also seen a wide array of practices for defining these measurements. Moreover, the EBA highlights (2013a, p. 28) that it is difficult to implement and monitor a common rule book and to assess the quality of national regulation and supervision.

- A common method to deviate from a common rule is for banks to change how riskweighted assets are calculated (Le Leslé and Avramova 2012). Vaughan (2011) reports that, faced with higher capital requirements, banks were reluctant to cut dividends or bonuses, while governments did not want them to reduce lending. Italian, German, Spanish, and UK banks changed their risk-weight-based modeling to improve their capital positions. The share of risk-weighted assets to total assets for European banks was half that of American banks. Within Europe, cross-country variation was large, ranging from $31 \%$ of French and Benelux banks to $52 \%$ of Spanish banks. An earlier EBA study found that some banks were using risk models that required them to hold $70 \%$ less capital than their peers (Masters 2013, P. 13). ${ }^{12}$

One of the key issues in calculating risk weighted assets is loss recognition. Basel rules contain a multi-part definition as to when default has occurred. Yet the ECB recognized that there were significant differences among countries in how bad debt is

\footnotetext{
${ }^{12}$ The analytics and data are so demanding that it is virtually impossible for outsiders to assess individual institutions.
} 
classified. Bloomberg reports (Sirletti and Black 2014, p. 1) "Bad-debt classification practices across Europe show material differences that, if not considered, would severely affect the consistency and credibility of the (bank review) exercise." The EBA began a consultation process on October 31, 2014 noting (EBA: 2014b, p. 6) "Firstly, some competent authorities set different absolute thresholds for retail and non retail portfolios. Secondly, in some jurisdictions the materiality threshold is not used, hence if any amount is past due more than 90 days the exposure is considered defaulted. Thirdly, some competent authorities did not set explicit limits but allow the institutions to define their own limits and make case-by-case evaluations..."

- Basel III prescribes that banks must hold more capital depending on their exposure to derivative contracts. Fonte (2013) reports on a method to circumvent this rule. The Italian Treasury is planning to introduce a new system of guarantees that would lower the cost to banks "to negotiate derivative contracts with the Treasury over government bonds, potentially increasing their ability to buy Italian debt. Under the new system, outlined in a draft decree linked to the budget law that parliament must pass by yearend, the Treasury and the banks will exchange cash sums on a short-term basis to guarantee their respective derivatives positions, based on their mark-to-market value. The draft bill said the new system was in accordance with IMF recommendations, adding it had been recently introduced in Britain while Sweden had used it for a long time."

- Criteria used by bank examiners to judge non-performing loans. Banca d'Italia (2013, p. 28 29) acknowledges that it applies a much stricter prudential rule than elsewhere in the EZ and has calculated that if the foreign criteria had been applied instead of her own, the ratio of non-performing loans to total loans in Italian banks, as of June 2012, would have dropped by approximately 4 percentage points.

- Another source of country heterogeneity is the treatment of deferred tax assets which result from losses that may be applied to future earnings. Under Basel III, deferred tax assets do not count towards capital. ${ }^{13}$ Nonetheless, it is still worth noting different practices aimed at enhancing banks' balance sheets. Italy allowed banks to reclassify deferred tax assets as tax credits. Spanish banks had 50 billion euro of deferred tax

\footnotetext{
${ }^{13}$ They are uncertain since a weak bank could fail before it had earned enough to utilize its tax assets.
} 
assets and lobbied the government to follow the Italian example. Buck (2013b, p. 14) reports that deferred tax assets made up $83 \%$ of the tangible book value for one bank and $64 \%$ for another. This would be either a deviation from the new global Basel rules or would imply a higher public debt by an equivalent amount.

- Another example of heterogeneity occurred in January of 2014, when a new Italian decree-law revalued the shares of Banca d'Italia — owned by a select group of banks, insurance companies, and a couple of public institutions - from an aggregate value of 156,000 euro to 7.5 billion euro. The shares will also be entitled to a maximum annual dividend of $6 \%$ of the revalued shares (Visco 2013). This decree law has been very controversial because it is seen as an artificial boost to the balance sheets and income statements of those banks that are major owners of Banca d'Italia shares (Coltorti 2013). ${ }^{14}$ Furthermore, capital gains on these shares booked at fair value will be included in Common Equity Tier 1 capital. $^{15}$

- Authorities use stress tests to signal the soundness of the banking system. Early European stress tests were of questionable value. Within four months of stress tests conducted in 2010, two Irish banks that passed the test were in difficulty (Jenkins 2010 , p. 2). One bank that passed the test with a $6.5 \%$ Tier 1 capital ratio subsequently failed. Some countries refused to publish details of their stress tests. Many used lenient stresses. Each country's regulator was allowed to apply its own stresses subject to guidance from the European regulatory committee. The timing of the test can be set strategically. Smyth (2013, p.14) reports that "Dublin has won approval from international lenders to delay the next round of banking stress tests until 2014, despite concerns over the health of bank. The new round of stress tests would likely impose lower capital requirements on Irish banks, compared with the minimum 10.5\% core tier one capital set in the last stress tests in 2011." Still another example is to "extend and pretend." By this method, banks roll over loans before maturity so that loans cannot be classified as in default or in arrears (Buck 2013a, p. 15).

Finally, the EBA launched a consultation in 2014 into allowing banks to use shorter

\footnotetext{
${ }^{14}$ The other objection is that this decree law abrogates a law of 2005, which has never been enforced, that would transform the Banca d'Italia into a state-owned institution. Intesa San Paolo owns $42.4 \%$ of the shares, Unicredit $22.1 \%$, and Generali $6.37 \%$. The new law prescribes a maximum ownership concentration of $3 \%$, which means that a sizeable capital gain can be realized from the sale of the excess shares. The ECB has objected to the decree law on several grounds but also because Banca d'Italia may be induced to be a buyer of those excess shares at above-market values.

${ }^{15}$ Inclusion in CET1 is also permissible if shares are booked as available for sale, starting in 2015 (Visco 2013).
} 
data periods for the calculation of risk parameters, for example using a minimum of two years rather than the five years that is currently required (EBA 2014a). However, it is recognized that more than one cycle is required to capture historical loss detail and two years would pick up little risk. For example, the UK Financial Services Authority had earlier required banks to either pick up 1992 data or stress for a major break in the riskiness of mortgage portfolios. This permission would have differential effects with the better managed banks that are able to use longer data series to calculate loss parameters.

\section{Conclusions}

Since Basel I, financial regulation has shifted from oligopoly clubs managed by the largest countries to expansive clubs (committees). Expansive clubs are more difficult to create and, once created, are more costly to manage and generate consensus. More importantly, an expansive club has to agree to terms that are closer to the preferences of soft-regulation members than of strict-regulation members. Yet, once a global agreement, such as Basel III, is reached, the transposition is left to national or regional regulators. It is in this implementation stage as well as in supervision, monitoring, and enforcement that deviations from Basel III standards are bound to occur. This is an issue not only for the entire membership of the Basel Committee on Banking Supervision (BCBS) but also for the sub-group consisting of EU member countries. In each case, the difficulties of achieving agreements will lead to lower standards.

This paper has emphasized two important sources of deviations from the Basel III global rules. The first is the difference between the EU and the US. The EU has adopted minimum regulatory standards and a single rulebook to be consistent with the principle of the single market: a race to the top would have undermined such a principle and given rise to political dissent and regulatory arbitrage. The US, seeking to repair the reputational damage of having started the sub-prime financial crisis, wants to set tighter standards than Basel III. While not discussed in this paper, the UK, Switzerland, and Canada are more in line with the US than the EU. Other countries, including but not limited to Australia, Austria, the Netherlands, and Sweden have also set higher standards. The second is deviations across EU members, in particular members of the EZ, driven by differences in country characteristics, regulatory preferences, and tradeoffs between 
regulatory stringency and economic activity. The dictates of a monetary union without a fiscal union have reduced the degree of freedom available to national policymakers who may seek to offset them by a more flexible interpretation of global rules of regulation and supervision. The complexity of Basel III will facilitate this process, as demonstrated by the numerous examples offered in this paper.

On the other hand, one cannot rule out that the EU as a whole may ultimately compromise on global prudential standards. In February 2014, it was reported that the European Commission was willing to accept securitizations in liquidity buffers even though the European Banking Authority put most securitizations in the lowest possible liquidity category (Sanderson 2014, p. 1). The difficulty of initiating, monitoring, and disciplining global standards makes them vulnerable to deviations.

The European Union purports to adopt guidance from the BCBS. Yet, the EU supports weaker regulation and more delayed implementation than is generally favored by other members of the BCBS or Financial Stability Board (FSB). Furthermore, the EU seems prepared to compromise on global prudential standards adopted within its jurisdiction, while the BCBS and the European Banking Authority (EBA) monitor adherence to their standards. This suggests a collision between clubs.

Possible policy implications are presented below:

- The best argument for financial regulation rests on managing network externalities.

- International standards are a type of public good.

- Agreements and standards are products of negotiations in heterogeneous clubs.

- Club member face different trade-offs, including short-term economic stimulus versus longer term prudent financial standards, welfare of banks versus welfare of taxpayers and welfare of labor.

- The composition of these clubs has shifted from hegemonic management by the United States after the Second World War to expansive clubs.

- Multiple clubs and multiple memberships create conflicts in the intersection of the interests of different clubs negotiating to create acceptable international solutions.

- Basel III standards are a good case in point: delayed implementation, clear lowering of initially agreed standards on capital, leverage and liquidity, as well as wide latitude in implementation have made compatible many diverse interests.

- Once a global agreement, such as Basel III, is reached, the transposition is left to national or regional regulators. Deviations from Basel III standards are bound to 
occur in the implementation stage.

- Two important sources of deviations from the Basel III global rules have emerged. The first is the adoption by the EU of minimum regulatory standards and a single rulebook applicable to all financial institutions.

- The second is the dual-regulatory system adopted by the US: one, with tighter standards than Basel III, is applicable to very large banks and the other, with Basel III like standards, is applicable to community banks.

Received 16 April 2014, Revised 6 September 2014, Accepted 18 December 2014

\section{References}

Alessandrini, Pietro, Fratianni, Michele, Hallett, Hughes Andrew and Andrea Presbitero. "External imbalances and fiscal fragility in the euro area." Open Economies Review 25 (2014):3-34.

Banca d'Italia, Rapporto sulla Stabilità Finanziaria-April. Rome: Banca d'Italia, 2013.

Bank for International Settlements. Important Steps Towards Completion of Post-Crisis Regulatory Reforms Endorsed by Group of Governors and Heads of Supervision. Basel: Bank for International Settlements, 2014.

Basel Committee on Banking Supervision, Report to G20 Leaders on Monitoring and Implementation of Basel III Regulatory Reforms. Basel: Bank for International Settlements, 2013.

Bayne, Nicholas. "Do we Need the G8 Summit? Lessons from the Past, Looking Ahead to the Future", in New Perspectives on Global Governance, edited by Michele Fratianni, John Kirton, Alan Rugman and Paolo Savona. Aldershot: Ashgate, 2005.

Bloomberg, "Banks Win 4-year Delay as Basel Liquidity Loosened," January 7, 2013.

Board of Governors of the Federal Reserve System, Basel Regulatory Framework-US Implementation. Washington, DC: Board of Governors of the Federal Reserve System. Accessible http://www.federalreserve.gov/bankinforeg/basel/USImplementation. 
htm\#baseIII).

Boughton, James M., Silent Revolution: The International Monetary Fund 1979-1989. Washington D.C., International Monetary Fund, 2001.

Braithwaite, Tom and Patrick Jenkins. "JPMorgan Chief Says Bank Rules 'Anti-US."” Financial Times, September 12, 2001.

Buck, Tobias. “Spanish Banks Face $€ 10$ bn Bad Loans Gap.” Financial Times, May 24, 2013a.

Buck, Tobias. "Spanish Lenders on Brink of Tax Win.” Financial Times, September 12, 2013b.

Carbo-Valverde, S., Kane, E.J., Rodriguez-Fernandez, F. "Regulatory Arbitrage in Cross-Border Banking Mergers within the EU." Journal of Money, Credit, and Banking 44 (2012):1609-1629.

Casella, Alessandra. "Participation in a Currency Union." The American Economic Review 82(1992): 847-863.

Coltorti, Fulvio. “Quel Pasticciaccio Brutto di Via Nazionale.” Linkiesta, December 15, 2013. Accessible www.linkiesta.it/bankitalia-privati.

Council of the European Union. European Council of 18/19 June 2009. Brussels: Presidency Conclusions, 2009: 11225/2/09 REV 2.

Dellas, Harris and George Tavlas. "The Gold Standard, the Euro and the Origins of the Greek Sovereign Debt Crisis." Cato Journal 33(2013): 491-520.

European Banking Authority. Interim Results of the EBA Review of the Consistency of Risk Weighted Assets. Brussels: European Banking Authority, 2013a (February 26).

European Banking Authority. EU-wide Transparency Exercise 2013- Summary Report. Brussels: European Banking Authority, 2013b (December 16).

European Banking Authority. Draft Regulatory Technical Standards on the Conditions According to Which Competent Authorities May Grant Permission for Data Waiver, Consultation Paper. Brussels: European Banking Authority, 2014a (February).

European Banking Authority. Draft Regulatory Technical Standards on Materiality Threshold of Credit Obligation Past Due Under Article 178 of Regulation (EU) 
575/2013, Consultation Paper. Brussels: European Banking Authority, 2014b (October 31).

European Central Bank. Aggregate Report on the Comprehensive Assessment. Frankfurt: European Central Bank, 2014 (October).

European Commission. A Comprehensive EU Response to the Financial Crisis: a Strong Financial Framework for Europe and a Banking Union for the Eurozone. Brussels: European Commission, 2013a (July 10).

European Commission. CRD IV. Brussels: European Commission, 2013b. Accessible http://ec.europa.eu/internal_market/bank/regcapital/legislation_in_force_en.htm\# maincontentSec1

Fonte, Giuseppe. "Italy Plans to Offer Guarantees on Government Bond Derivatives." Reuters, October 21, 2013. Accessible http://www.reuters.com/article/2013/10/21/italyderivatives-guarantees-idUSL5N0IB1XE20131021

Fratianni, Michele and John Pattison. "The Economics of International Organizations." Kyklos 35(1982): 244-262.

Fratianni, Michele and John Pattison. "The Bank for International Settlements: An Assessment of its Role in International Monetary and Financial Policy Coordination." Open Economies Review, 12 (2001): 197-222.

Funabashi, Yoichi. Managing the Dollar: From the Plaza to the Louvre. Washington, DC: Institute for International Economics, 1988.

Gore, Gareth. "European Banks Increase Sovereign Bets Despite Risks." International Financing Review, October 29, 2014. Accessible http://ifre.com/european-banksincrease-sovereign bets-despite-risks/21170993.article.

Guardian. “Greece’s Austerity: Democracy Tested to Destruction.” November 8, 2012.

Jenkins, Patrick. "Doubts Resurface on Credibility of Stress Tests." Financial Times, November 24, 2010.

Jones, Huw. "Regulators Ease New Bank Rule on Leverage to Aid Economy." Reuters, January12, 2014. Accessible http://www.reuters.com/article/2014/01/12/us-basel-banksidUSBREA0B0IX20140112

Karolyi, G. Andrew and Alvaro G. Taboada. "Regulatory Arbitrage and Cross-Border 
Bank Acquisitions.” Unpublished Paper, October, 2013.

Kindleberger, Charles. "Standards as Public, Collective and Private Goods." Kyklos, 36(1983): 377-396.

Kirton, John J. G20 Governance for a Globalized World. Aldershot: Ashgate, 2013.

Korinek, Anton and Jonathan Kreamer. "The Redistributive Effects of Financial Regulation: Wall Street versus Main Street.” BIS Working Papers 468, 2014.

Kupiec, Paul H. "Basel III: Some Costs Will Outweigh the Benefits." American Enterprise Institute Financial Services Outlook, November, 2013.

Le Leslé, Vanessa and Sofiya Avramova (2012), "Revisiting Risk-Weighted Assets -Why Do RWAs Differ Across Countries and What Can Be Done About It?" Working paper 12/90 International Monetary Fund, 2012.

Masson, Paul and John Pattison. "Financial Regulatory Reform: Using Models of Cooperation to Evaluate Current Prospects for International Agreement." Journal of Economic Asymmetries 5 (2009): 119-136.

Masters, Brooke and Norma Cohen. "Regulator in Capital Concession." Financial Times, June 30, 2011.

Masters, Brooke. "Bank Risk Weightings in Spotlight After EBA Uncovers Discrepancies.” Financial Times, February 27, 2013.

Merler, Silvia, and Jean Pisani-Ferry. "Sudden Stops in the Euro Area." Review of Economics and Institutions 3(2012): Article 5.

Olson, Mancur Jr. The Logic of Collective Action. Cambridge: Harvard University Press, 1965.

Olson, Mancur Jr. and Richard Zeckhauser. "An Economic Theory of Alliances.” Review of Economics and Statistics 48(1966): 266-279.

Panetta, Fabio. "On The special Role of Macroprudential Policy in the Euro Area." Amsterdam: De Nederlandsche Bank, June 10, 2014.

Rachman, Gideon. "Old Alliance Gives West a Chance for Final Stand.” G8 Summit. In Financial Times, June 17, 2013.

Sanderson, Owen. "EC Takes Securitization Further Down Rehab Path." Reuters, 
February 14, 2014. Accessible www.reuters.com/assets/print?aid=USL5NOLF1 EU20140214.

Sirletti, Sonia and Jeff Black. "ECB Sees Bad-Debt Rules as Threat to Credible Bank Review.” Bloomberg, January 14, 2014. Accessible http://www.bloomberg.com/news/ print/2014-01-13/ecb-sees-bad-dbet-rules-as-threat-to-credibility.

Shearman \& Sterling LLP. Basel III Framework: US/EU Comparison. London, September 17, 2013.

Smyth, Jamie. "Ireland Allowed to Delay Bank Tests." Financial Times, June 14, 2013.

Vaughan, Liam. "Financial Alchemy Foils Capital Rules as Banks Redefine Risk." Bloomberg, November 9, 2011. Accessible www.bloomberg.com/print/2011-11-09/ financial-alchemy.

Visco, Ignazio. 'Indagine Conoscitiva per L'istruttoria Legislativa sul Disegno di Legge n. 1188." Audizione del Governatore della Banca d'Italia al Senato della Repubblica. Rome: Banca d'Italia, 2013 (December 12). 


\section{Appendix 1. Countries and Clubs}

\begin{tabular}{|c|c|c|c|c|}
\hline Country's club membership & Country & $\begin{array}{c}\text { GDP } \\
\text { weight }\end{array}$ & $\begin{array}{c}\text { Bank credit } \\
\text { weight }\end{array}$ & $\begin{array}{c}\text { Stock value } \\
\text { traded weight }\end{array}$ \\
\hline G20, FSB, BCBS & Argentina & 0.66 & 0.14 & 0.00 \\
\hline G20, FSB, BCBS & Australia & 2.12 & 1.93 & 2.02 \\
\hline G10, BCBS & Belgium & 0.67 & 0.46 & 0.20 \\
\hline G20, FSB, BCBS & Brazil & 3.11 & 2.03 & 1.60 \\
\hline G7, G10, G20, FSB, BCBS & Canada & 2.51 & NA & 2.32 \\
\hline G20, FSB, BCBS & China & 11.36 & 10.43 & 11.19 \\
\hline G5, G7, G10, G20, FSB, BCBS & France & 3.61 & 2.91 & 2.16 \\
\hline G5, G7, G10, G20, FSB, BCBS & Germany & 4.73 & 3.43 & 2.35 \\
\hline FSB, BCBS & Hong Kong & 0.36 & 0.43 & 2.36 \\
\hline G20, FSB, BCBS & India & 2.54 & 1.15 & 1.20 \\
\hline G20, FSB, BCBS & Indonesia & 1.21 & 0.31 & 0.18 \\
\hline G7, G10, G20, FSB, BCBS & Italy & 2.78 & 2.76 & 1.46 \\
\hline G5, G7, G10, G20, FSB, BCBS & Japan & 8.23 & 16.86 & 6.93 \\
\hline G20, FSB, BCBS & South Korea & NA & NA & NA \\
\hline BSBC & Luxembourg & 0.08 & 0.08 & 0.00 \\
\hline G20, FSB, BCBS & Mexico & 1.63 & 0.45 & 0.23 \\
\hline G10, FSB, BCBS & Netherlands & 1.06 & 1.36 & 0.85 \\
\hline G8, G20, FSB, BCBS & Russia & 2.78 & 0.68 & 1.41 \\
\hline G20, FSB, BCBS & Saudi Arabia & 0.98 & -0.06 & 0.99 \\
\hline FSB, BCBS & Singapore & 0.38 & 0.22 & 0.30 \\
\hline G20, FSB, BCBS & South Africa & 0.53 & 0.59 & 0.60 \\
\hline BCBS & Spain & 1.83 & 2.44 & 2.07 \\
\hline G10, BCBS & Sweden & 0.72 & 0.62 & 0.72 \\
\hline G10, FSB, BCBS & Switzerland & 0.87 & 1.00 & 1.23 \\
\hline G20, FSB, BCBS & Turkey & 1.09 & 0.46 & 0.67 \\
\hline G5, G7, G10, G20, FSB, BCBS & United Kingdom & 3.41 & 4.18 & 4.78 \\
\hline G5, G7, G10, G20, FSB, BCBS & United States & 22.42 & 30.43 & 41.06 \\
\hline
\end{tabular}

(Notes) The data refer to 2012. The G10 started in 1961 with France, Germany, Japan, the UK, and the US (later to become the G5) plus Canada and Italy (later these seven would form the G7) plus Belgium, the Netherlands, and Sweden. Switzerland became an affiliated member in 1964; thus the G10 is in fact the G11. The initial objective of the group was to organize and fund the General Arrangements to Borrow, a facility that permitted 
the IMF to borrow from member country governments to finance the lending activity of the Fund. The G10 has also played a leading role in the OECD (in particular in its Economic Policy Committee and Working Party 3) and in the Bank for International Settlements where the G10 central banks meet once a month. The G5 started informally in 1973 when the US Treasury invited their counterparts in France, Germany, and the UK to the White House (hence the nickname Library Group) to discuss the repercussion of the demise of Bretton Woods. Japan joined later in the year. The collapse of the fixed exchange rate system was also responsible for the creation of the G7 at the Rambouillet meeting in France in 1975. The G20 started in 1999 with the objective of consulting and cooperating on issues related to the international financial system; for an extensive treatment of the G20, see Kirton (2013). The FSB is the brainchild of the G20 at its 2009 meeting in London with a mandate of monitoring and proposing recommendations on the world's financial system. BCBS was established in 1974 by the G10 central banks. It is composed of supervisory authorities.

(Sources) World Bank, World Development Indicators, http://data.worldbank.org/products/wdi.

\section{Appendix 2. Clubs and BCBS}

(world shares of critical indicators)

\begin{tabular}{|l|r|r|r|r|r|r|r|r|}
\hline & \multicolumn{3}{|c|}{ GDP in US dollars } & \multicolumn{3}{c|}{$\begin{array}{c}\text { Domestic bank credit, } \\
\text { \% GDP }\end{array}$} & \multicolumn{2}{c|}{$\begin{array}{c}\text { Stocks traded, } \\
\text { \% GDP }\end{array}$} \\
\hline & 1973 & 2007 & 2012 & 1973 & 2007 & 2012 & 2007 & 2012 \\
\hline G5 & 58.63 & 48.86 & 42.40 & 71.28 & 66.09 & 57.82 & 65.22 & 57.28 \\
\hline CAN + IT & 6.51 & 6.29 & 5.30 & 5.86 & 5.46 & 2.76 & 3.90 & 3.78 \\
\hline BE + NL + SW + CH & 3.72 & 3.82 & 3.33 & 2.68 & 3.84 & 3.44 & 4.73 & 3.00 \\
\hline BRIC countries & 6.62 & 13.10 & 19.79 & 1.49 & 7.53 & 14.30 & 10.08 & 15.40 \\
\hline Remaining G20 & 5.62 & 6.97 & 8.21 & 2.44 & 3.16 & 3.83 & 2.92 & 4.68 \\
\hline Additional BCBS & 1.98 & 3.32 & 2.65 & 1.66 & 3.68 & 3.18 & 4.20 & 4.73 \\
\hline Rest of the world & 16.92 & 17.65 & 18.33 & 14.59 & 10.25 & 14.68 & 8.94 & 11.13 \\
\hline
\end{tabular}

(Notes) The G5 consists of France, Germany, Japan, the United Kingdom, and the United States; CAN = Canada, IT = Italy, BE = Belgium, NL = Netherlands, SW = Sweden, $\mathrm{CH}=$ Switzerland; the G7 = the G5 + $\mathrm{CAN}+\mathrm{IT} ; \mathrm{G} 10=\mathrm{G} 7+\mathrm{BE}+\mathrm{NL}+\mathrm{SW}+\mathrm{CH}$; BRIC countries: Brazil, Russia, India, and China; Remaining G20 = Argentina, Indonesia, S. Korea, Mexico, S. Arabia, S. Africa, and Turkey, G20 = G7 + BRIC countries + remaining G20; additional BCBS: Hong Kong, Luxembourg, Singapore, and Spain. Missing data: 1973, GDP for Russia and Switzerland; 1973, 2007, and 2012 GDP for S. Korea; 1973, bank credit for China. Hong Kong, Luxembourg, Russia, and Switzerland; 2012, bank credit for Canada.

Comments. In terms of world GDP shares, the G5 has dropped from 53\% in 1973 (the end of Bretton Woods) to $49 \%$ in 2007 (the year before the financial crisis) and to $42 \%$ in 2012 (five years into the crisis). The loss of G5 share finds a counterpart in the gain by emerging market economies, in particular the BRIC group. A relative decline has occurred also in terms of financial power. Financial power is measured here with two indicators: domestic bank credit and value of stock traded as a percentage of world GDP and normalized so that the shares add to 100. The first indicator is biased in favor of bank-centric financial systems like Germany's; the second 
http://dx.doi.org/10.11130/jei.2015.30.1.1

indicator is biased in favor of market-based financial systems like the United Kingdom's. In terms of domestic bank credit world shares, the G5 has dropped from $71 \%$ in 1973 to $66 \%$ in 2007 and 58\% in 2012; again, the financial crisis has sharply accentuated the decline. For the value of stocks traded, this paper has no data for 1973 and the comparison is limited to the recent past: the G5 dropped from $65 \%$ in 2007 to $57 \%$ in 2012 . The emerging market economies have picked most of the G5 losses in these two financial indicators. In sum, the relative decline of the traditional core industrial countries has been considerable, although more in the output market than in the financial markets.

(Sources) World Bank, World Development Indicators, http://data.worldbank.org/products/wdi. 